www.jmscr.igmpublication.org Impact Factor 5.244

Index Copernicus Value: 83.27 ISSN (e)-2347-176x ISSN (p) 2455-0450 crossref DOI: _https://dx.doi.org/10.18535/jmscr/v4i11.37

\title{
Diagnostic Utility of Cell Block Method versus Cytospin Method in Pleural and Peritoneal Fluid Cytology
}

\author{
Mulkalwar $\mathbf{M}^{1}$, Chandrakar $\mathrm{J}^{2 *}$, Kujur $\mathbf{P}^{3}$, Gahine $\mathbf{R}^{4}$, Swarnakar $\mathrm{S}^{5}$, Bhaskar L.V.K.S $\mathbf{S}^{6}$ \\ 1,2,3 Department of Pathology, Pt. J.N.M. Medical College, Raipur (C.G.), INDIA \\ ${ }^{4}$ Department of Pathology, Government Medical College, Rajnandgaon (C.G.), INDIA \\ ${ }^{5}$ Department of Biochemistry, Pt. J.N.M. Medical College, Raipur (C.G.), INDIA \\ ${ }^{6}$ Sickle cell Institute Chhattisgarh, Raipur (C.G.), INDIA \\ Corresponding Author \\ Dr (Mrs.) Jayanti Chandrakar (MD) \\ Associate Professor, Department of Pathology, Pt. J.N.M. Medical College, Raipur,(C.G.) \\ Email: drjayantichandrakar@gmail.com
}

\begin{abstract}
Background: Cytological evaluation of body cavity fluid is diagnostically challenging. Improved ethanol formalin fixative is used which offer excellent cytomorphological features. Cell blocks prepared from residual tissue fluids or effusion obtained by aspiration, can be useful adjunct to smear for establishing a more definitive cytopathologic diagnosis. .

Methods: A total of 170 fluid specimens were examined for cytospin smear and cell block method. Out of 170 fluids, 102 were peritoneal and 68 were pleural. Each fluid specimen was subjected to cytospin smear (CSS) technique, and 10\% alcohol-formalin cell block (CB) technique. Overall morphological details, cellularity, architecture, nuclear and cytoplasmic details were studied in both CSS and CB techniques.

Results: In this study, analysis body fluid specimens using cytospin smear and cell block methods revealed that there is no difference between cytospin smear method and CB in defining the benign, fungal and inflammatory conditions. However, CB method could able to identity papillary pattern more efficiently than the cytospin method.

Conclusion: Although there was no statistical difference between the results obtained by the cytospin and cell block methods, cell block method in our study accurately diagnosed the cases which were missed or incompletely diagnosed on cytospin smear method. Thus cell block proved to be superior method for the study of effusion as compared to cytospin smear. As the cell blocks permit longer storage and additional analysis such as immunohistochemistry (IHC) and microarray, it should be adopted additionally for effusion cytology.
\end{abstract}

Keywords: Cell block, Cytospin, Cytodiagnosis, adenocarcinoma, Effusion. 


\section{Introduction}

Effusion cytology is the study of individual cells from aspirated material for the diseases diagnoses, accurate diagnosis of cells of serous fluids is a major challenge and distinguishing benign from malignant may require meticulous screening ${ }^{(1,2)}$. Cytology gives the first indication of malignancy in one third of malignant effusions and due to bland morphological details of cells, overcrowding or overlapping of cells, cell loss, and processing methods of the laboratory, it is very difficult to achieve ${ }^{(1)}$. The cytological examination of serous effusions is well-accepted as it provides a definitive diagnosis that helps in staging, prognosis and management of the patients in malignancies ${ }^{(3,4)}$. Further, it gives information about various inflammatory and noninflammatory lesions of serous membrane ${ }^{(5-7)}$. Recent new biological discoveries and analytical breakthroughs led the usage of several nonstandard body fluids including saliva, peritoneal, pleural, synovial, wound, drain and washout fluids for the diagnosis of human diseases ${ }^{(8)}$. The information provided by body fluid analysis helps the clinician in formulating therapy and prognosis. There are a wide range of cytological techniques available to analyse body fluids, from simple direct smears, cytospin smear to cell block methods. Selection of a particular method will depends on the aspiration preparation skill, location of the aspiration to the preparation lab and expertise of the cytopathologist ${ }^{(9)}$.

Cytospin smear method is designed to concentrate cells that are found in small numbers. This method allows the cells to be spun at various speeds and times to ensure formation of a monolayer of cells for the best assessment of the cells ${ }^{(6)}$. The cell block (CB) technique is one of the oldest methods for the evaluation of body cavity fluids, in which small tissue fragments in a fluid specimen are processed to form a paraffin block ${ }^{(2,5,6,10)}$. The main advantages of the $\mathrm{CB}$ technique are preservation of tissue architecture and obtaining multiple sections for special stains and immunohistochemistry ${ }^{(5,6,10-12)}$. Further, a good
$\mathrm{CB}$ can be very useful for molecular diagnostic studies such as fluorescence in situ hybridization, polymerase chain reaction, and cDNA microarray analyses ${ }^{(13)}$. The present study is aimed to compare the relative usefulness of cytomorphological features by using cytospin smear and cell block methods of body fluid analysis in the diagnosis of peritoneal and pleural effusions.

\section{Materials and Methods}

The present study was an observational prospective study conducted on 170 body fluid specimen collected by paracentesis for the diagnosis of effusion cytology by CSS and CB method that referred Histopathology and Cytology laboratory, Department of Pathology, Pt. J.N.M. Medical College \& Dr. B.R.A.M. Hospital, Raipur (Chhattisgarh), India, between February 2014 and August 2015. Institutional ethics committee of Pt. J.N.M. Medical College, Raipur has approved this study. Informed written consent was collected from the relatives of the patients. Complete demographic information and a thorough medical history with relevant clinical details were collected for each sample. About $20 \mathrm{ml}$ of fresh pleural/peritoneal fluid specimens were aspirated freshly from patients by following all aseptic precautions and local anesthesia. The gross examination of the fluid is done by describing the color, clarity, granularity, coagulum etc. Of the 20 $\mathrm{ml}$ specimen, only $3 \mathrm{ml}$ was used for cytospin smear method and rest was used for cell block preparation. The protocol adopted respectively for the cytospin smear and cell block techniques were briefly as follows.

The cytospin technique involves the use of cytospin slides that are assembled with a slide filter card and sample delivery chamber, secured by a plastic clip. About $3 \mathrm{ml}$ sample was centrifuged at $700 \mathrm{rpm}$ for 6 minutes in a Thermo Shandon cytocentrifuge. The cell suspension that spun onto a microscope slide was absorbed onto filter paper while the centrifuge is spinning. Smear were prepared \& stained with Papanicolaou stain/ Hematoxylin and Eosin ${ }^{(5)}$. In cell block 
technique, $10 \mathrm{ml}$ sample of fluid sample was mixed with equal volume of AF fixative $(10 \mathrm{ml}$ of $10 \%$ alcohol-formalin (i.e., nine parts of $90 \%$ alcohol and one part of $7.5 \%$ formalin), kept for one hour and centrifuged at $2500 \mathrm{rpm}$ for 15 minutes for obtain cell sediment. The supernatant was discarded and a further $3 \mathrm{ml}$ of fresh $10 \%$ alcohol-formalin was added once again to the sediment, than kept for one day. On the following day, the sediment containing the cell button of the fluid sample was scooped out on to the Whatman's filter paper and processed in automatic tissue processor for routine histopathology section. From the paraffin embedded cell button (cell block), 4-6 $\mu$ thickness sections were prepared and stained with the Harris hematoxylin and eosin stain (5). The fluid specimens were categorized based on the morphological criteria including cellularity, arrangement of cells, nuclear and cytoplasmic details of each specimen. Final diagnosis of Benign, suspicious for malignancy and malignant effusion of the patient was made based on the clinical history, laboratory tests, radiological examination and cytological examination based on the cytospin and cell block techniques. To assess the difference between cytospin and cell block techniques chi-square test statistics were adopted.

\section{Results}

All the 170 body fluid specimens were subjected to the Cytospin smear and the $\mathrm{CB}$ techniques. Out of 170 patients, 67 patients $(39.4 \%)$ were males and 103 patients $(60.6 \%)$ were females with male:female ratio of $1: 1.5$. Of the 170 specimens analysed, $102(60 \%)$ were of ascitic fluid and 68 $(40 \%)$ were of pleural fluid (Table 1). Of all the effusions, $76.5 \%$ were turbid and $23.5 \%$ were clear (Table 1). Variation in the microscopic impression obtained by cytospin smears and cell block methods in different fluid types was presented in table 2. There was no difference between cytospin smear method and $\mathrm{CB}$ in defining the benign, fungal and inflammatory conditions. However, CB method was more efficient (22.9\%) in diagnosing malignant condition when compared to CSS method $(20.0 \%)$. Further inquiry revealed that the both methods defined more neoplastic impression in ascitic fluids and nonneoplasrtic impression in pleural fluids (Table 2). Diagnostic characterization of neoplastic and non-neoplastic lesions using cytospin smear and cell block methods showed that there is no difference between these two methods for non-neoplastic conditions (Table 3). Variations in patterns of malignant cases diagnosed using cytospin smear and cell block methods was documented in table 4. Although both cytospin and CB methods are similar in defining the cellular pattern, $\mathrm{CB}$ method could able to identify papillary pattern more efficiently in the present sample (Table 4). The differences in the photomicrograph obtained through the cytospin smear and cell block is depicted in figure 1. Upon Haematoxylin and Eosin stain, cytospin smear showed cluster \& scattered malignant cells, cells arranged in acinar pattern with nuclei were eccentrically pushed and mucin filled cytoplasm in hemorrhagic background giving the impression of adenocarcinoma of ovary. The same sample using cell block method and Haematoxylin and Eosin stain showed a hyperchromatic papillary cluster of malignant cells with stratification of cells and fibrovascular core with stratification of hyperchromatic nuclei in haemorrhagic background indicating the papillary adenocarcinoma of ovary (Figure 1).

Table 1: Characteristics of the fluid specimen used in the study

\begin{tabular}{llll}
\hline & Turbid fluid & Clear fluid & Total \\
\hline Pleural fluid & $50(38.5)$ & $18(45.0)$ & $68(40.0)$ \\
Ascites fluid & $80(61.5)$ & $22(55.0)$ & $102(60.0)$ \\
Total & 130 & 40 & 170 \\
\hline
\end{tabular}


Table 2: Variation of microscopic impression obtained by cytospin smears and cell block methods in different fluid types.

\begin{tabular}{lllllll}
\hline & \multicolumn{5}{l}{ Cytospin smear method } & \multicolumn{3}{l}{ Cell block method } \\
\cline { 2 - 7 } Microscopic impression & Total & Pleural fluid & Ascites fluid & Total & Pleural fluid & Ascites fluid \\
\hline Benign & $45(26.5)$ & $14(20.6)$ & $31(30.4)$ & $45(26.5)$ & $14(20.6)$ & $31(30.4)$ \\
Fungal & $2(1.2)$ & $1(1.5)$ & $1(1.0)$ & $2(1.2)$ & $1(1.5)$ & $1(1.0)$ \\
Inflammatory & $62(36.5)$ & $34(50.0)$ & $28(27.5)$ & $62(36.5)$ & $34(50.0)$ & $28(27.5)$ \\
Malignant & $34(20.0)$ & $10(14.7)$ & $24(23.5)$ & $39(22.9)$ & $12(17.6)$ & $27(26.5)$ \\
Suspicious of malignant & $10(5.9)$ & $4(5.9)$ & $6(5.9)$ & $5(2.9)$ & $2(2.9)$ & $3(2.9)$ \\
Others & $17(10.0)$ & $5(7.4)$ & $12(11.8)$ & $17(10.0)$ & $5(7.4)$ & $12(11.8)$ \\
\hline
\end{tabular}

Table 3: Diagnostic characterization of neoplastic and non-neoplastic lesions using cytospin smear and cell block methods.

\begin{tabular}{|c|c|c|}
\hline Diagnosis & Cytospin & Cell block \\
\hline \multicolumn{3}{|c|}{ Non-neoplastic } \\
\hline RMs & $18(16.5)$ & $18(16.5)$ \\
\hline RMs with inflammation & $27(24.8)$ & $27(24.8)$ \\
\hline Acute inflammation & $3(2.8)$ & $3(2.8)$ \\
\hline Chronic inflammation & $40(36.7)$ & $40(36.7)$ \\
\hline Acute \& chronic inflammation & $19(17.4)$ & $19(17.4)$ \\
\hline Fungal & $2(1.8)$ & $2(1.8)$ \\
\hline Chi square $\mathrm{p}$ value & & 1.00 \\
\hline \multicolumn{3}{|c|}{ Neoplastic } \\
\hline ADCA & $25(56.8)$ & $28(63.6)$ \\
\hline SCC & $4(9.1)$ & $5(11.4)$ \\
\hline RCT & $3(6.8)$ & $3(6.8)$ \\
\hline MM & $1(2.3)$ & $1(2.3)$ \\
\hline PDCA & $1(2.3)$ & $2(4.5)$ \\
\hline STBM & $10(22.7)$ & $5(11.4)$ \\
\hline Chi square $p$ value & & 0.492 \\
\hline
\end{tabular}

RMs: Reactive mesothelial cells; ADCA: Adenocarcinoma; SCC: Squamous cell carcinoma; RCT: Round cell tumor; MM: malignant melanoma; PDCA: Poorly differentiated carcinoma; STBM: Suspected to be malignant.

Table 4: Variations in patterns of malignant cases diagnosed using cytospin smear and cell block methods.

\begin{tabular}{lllll}
\hline S.No. & Subtypes of malignancy & Various pattern showed & Cytospin & Cell block \\
\hline 1. & Adenocarcinoma & Scattered/clustered/acinar & $17(50)$ & $16(41)$ \\
& & Papillary \& acinar pattern & $4(11.8)$ & $4(10.3)$ \\
& & Mucinous papillary & $0(0)$ & $2(5.1)$ \\
& & Serous papillary with psamomma bodies & $0(0)$ & $1(2.6)$ \\
& & Signet ring carcinoma & $2(5.9)$ & $2(5.1)$ \\
& & Brochioloalveolar & $0(0)$ & $1(2.6)$ \\
& & Poorly differentiated adenocarcinoma & $2(5.9)$ & $2(5.1)$ \\
2. & Squamous cell carcinoma & Moderately differentiated & $2(5.9)$ & $2(5.1)$ \\
& & Poorly differentiated & $2(5.9)$ & $3(7.7)$ \\
3. & Malignant round cell tumor & & $3(8.8)$ & $3(7.7)$ \\
4. & Malignant melanoma & & $1(2.9)$ & $1(2.6)$ \\
5. & Poorly differentiated carcinoma & & $1(2.9)$ & $2(5.1)$ \\
\hline
\end{tabular}


Figure 1: Photomicrograph of cytospin smear and cell block methods.

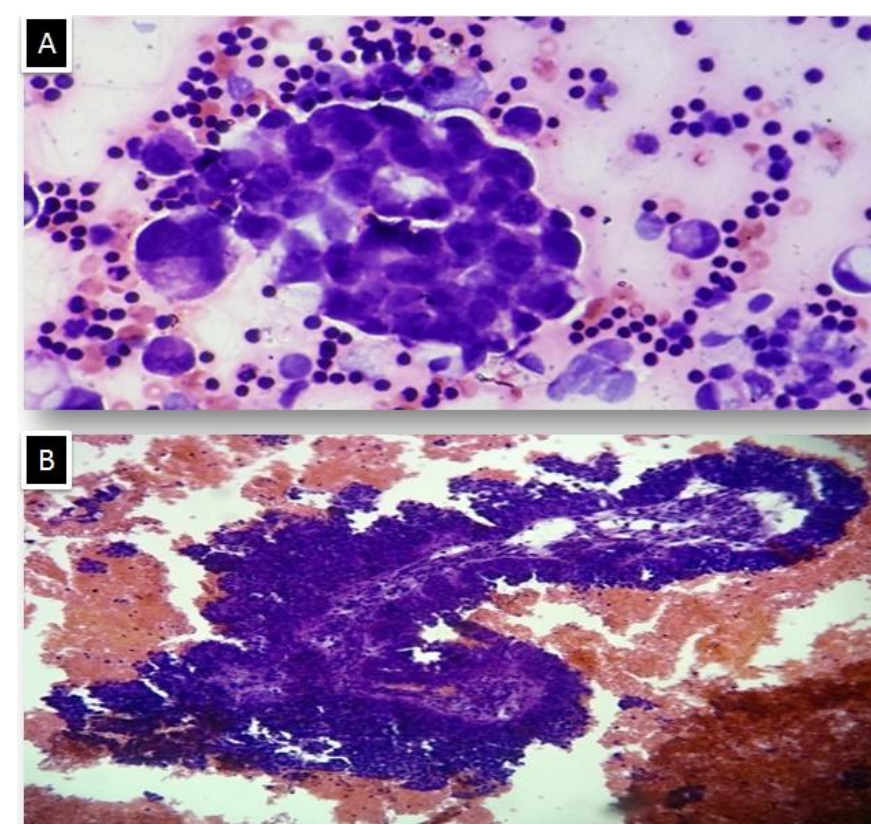

Cytospin smear indicating adenocarcinoma of ovary (H \& E - 400x); B. Cell block indicating the papillary adenocarcinoma of ovary $(\mathrm{H} \& \mathrm{E}$ 400x).

\section{Discussion}

Analysis of 170 body fluid specimens using cytospin smear and cell block methods revealed that there is no difference between cytospin smear method and $\mathrm{CB}$ in defining the benign, fungal and inflammatory conditions. However, CB method could able to identify papillary pattern more efficiently than the cytospin method. Further, photomicrograph obtained through the cell block method provided better impression of malignancy than that depicted by cytospin smear method.

Multiple independent studies conducted on effusion cytology have shown that the cytospin and cellblocks methods are superior to conventional method in diagnosing the effusions. Conventional smears failed in making conclusive diagnosis due to lack of morphological details of the representative cells in the sample ${ }^{(6)}$. Whereas in cytospin preparations allow the preservation of cellular details and reduce the overlapping of cells (14). Manifestation of glandular formations and acinar groupings in cell block method made it as a superior to smear based methods ${ }^{(5,15)}$. Direct comparison of effusion analysis by cytospin and cell block methods revealed that there is no difference between these methods ${ }^{(16)}$. Scope for performing immunohistochemistry and microarray on cellblocks is an added advantage of cellblock method ${ }^{(17)}$. Although, cell block preparations facilitate better diagnosis of lesions, sometimes fails in providing conformation and lead to suspicion of malignancy. In the present study, five cases $(2.94 \%)$ could not achieve final diagnosis by all available clinical details \& morphological features. A comparative study reported that $0.67 \%$ cases failed to achieve final diagnosis by all modalities ${ }^{(10)}$. Adenocarcinoma is the commonest malignancy found in body effusions (1,6,10,18-20). The present study report well appreciated acinar, mucinous papillary, serous papillary, bronchioloalveolar, signet ring carcinoma patterns by cell block than cytospin smears. Among hemorrhagic malignant effusions, cell blocks give better appreciation of malignant cells due to formation of two layers in sediment. But care should be taken during embedding the cell button that cutting surface should be the upper part of the sediment to avoid more hemorrhagic background, or glacial acetic acid could be mixed in hemorrhagic effusions to obtain clear cellular details.

\section{Conclusions}

Although there was no statistical difference between the results obtained by the cytospin and cell block methods, cell block method in our study accurately diagnosed the cases which were missed or incompletely diagnosed on cytospin smear method and recognition of specific histological patterns of diseases is possible by using cell block method. It is also useful for special stains and immunohistochemistry and can give morphological details by preserving the architectural patterns. Storage of slides \& blocks for retrospective studies is easy by using cell block method. Thus cell block proved to be superior method for the study of effusion as compared to cytospin smear. 


\section{References}

1. Thapar M, Mishra RK, Sharma A, Goyal V. Critical analysis of cell block versus smear examination in effusions. Journal of cytology. 2009;26(2):60-4.

2. Koksal D, Demirag F, Bayiz H, Koyuncu A, Mutluay N, Berktas B, et al. The cell block method increases the diagnostic yield in exudative pleural effusions accompanying lung cancer. Turk patoloji dergisi. 2013;29(3):165-70.

3. Walker S, Bibby AC, Maskell NA. Current best practice in the evaluation and management of malignant pleural effusions. Therapeutic advances in respiratory disease. 2016.

4. Choong CK. Management of benign and malignant pleural effusions. Thoracic surgery clinics. 2013;23(1):ix.

5. Shivakumarswamy U, Arakeri SU, Karigowdar MH, Yelikar B. Diagnostic utility of the cell block method versus the conventional smear study in pleural fluid cytology. Journal of cytology. 2012;29(1):11-5.

6. Joshi A, Mahajan N, Karmarkar PJ, Mahore SD. Diagnostic utility of various techniques used in body fluid cytology. IOSR Journal of Dental and Medical Sciences (IOSR-JDMS). 2014;13(1):13-8.

7. Pal S, Murmu D, Goswami BK. Ascitic Fluid Cytology in Suspected Malignant Effusions with Special Emphasis on Cell Block Preparation. Journal of Evolution of Medical and Dental Sciences. 2015;4 (60):10488-93.

8. Lippi G, Plebani M. Opportunities and drawbacks of nonstandard body fluid analysis. Clinical chemistry and laboratory medicine. 2016.

9. Conrad R, Cobb C, Raza A. Role of cytopathology in the diagnosis and management of gastrointestinal tract cancers. Journal of gastrointestinal oncology. 2012;3(3):285-98.
10. Bhanvadia VM, Santwani PM, Vachhani JH. Analysis of diagnostic value of cytological smear method versus cell block method in body fluid cytology: study of 150 cases. Ethiopian journal of health sciences. 2014;24(2):125-31.

11. Ensani F, Nematizadeh F, Irvanlou G. Accuracy of immunohistochemistry in evaluation of malignant pleural and peritoneal effusions. Polish journal of pathology : official journal of the Polish Society of Pathologists. 2011;62(2):95-100.

12. Ghosh I, Dey SK, Das A, Bhattacharjee D, Gangopadhyay S. Cell block cytology in pleural effusion. Journal of the Indian Medical Association.2012;110(6):390-2, 6 .

13. Symmans WF, Ayers M, Clark EA, Stec J, Hess KR, Sneige N, et al. Total RNA yield and microarray gene expression profiles from fine-needle aspiration biopsy and core-needle biopsy samples of breast carcinoma. Cancer. 2003;97(12):2960-71.

14. Siddiqui MT, Gokaslan ST, Saboorian MH, Carrick K, Ashfaq R. Comparison of ThinPrep and conventional smears in detecting carcinoma in bile duct brushings. Cancer. 2003;99(4):205-10.

15. Bhatia P, Dey P, Uppal R, Shifa R, Srinivasan R, Nijhawan R. Cell blocks from scraping of cytology smear: comparison with conventional cell block. Acta cytologica. 2008;52(3):329-33.

16. Mao YY, Yang M, Liu DG, Lin MH, Zhang LQ, Chen ZQ. [Evaluation of immunohistochemistry staining and cytologic diagnosis by using cell block sections prepared with effusion fluid cytology specimens]. Zhonghua bing li xue za zhi $=$ Chinese journal of pathology. 2009;38(8):547-50.

17. Khan N, Sherwani KR, Afroz N, Kapoor S. Usefulness of Cell Blocks Versus smears in Malignant effusion cases. Journal of cytology. 2006;23:129-32. 
18. Bista P. Comparison of the diagnostic accuracy of cell block with cytology smears in serous effusions. Kathmandu, Nepal. . Journal of Pathology of Nepal. 2013;3:482 -6.

19. Gaur D, Chauhan N, Kusum A, Harsh M, Talekar M, Kishore S, et al. Pleural fluid analysis - role in diagnosing pleural malignancy. Journal of cytology. 2007;24(4):183-8.

20. Shobha SN, Kodandaswamy CR. Utility of Modified Cell Block Technique in Cases of Pleural Effusion Suspected of Malignancy International Journal of Health Sciences and Research (IJHSR). 2013;3(1):33-8. 